\title{
Frederick William Beechey (1796-1856)
}

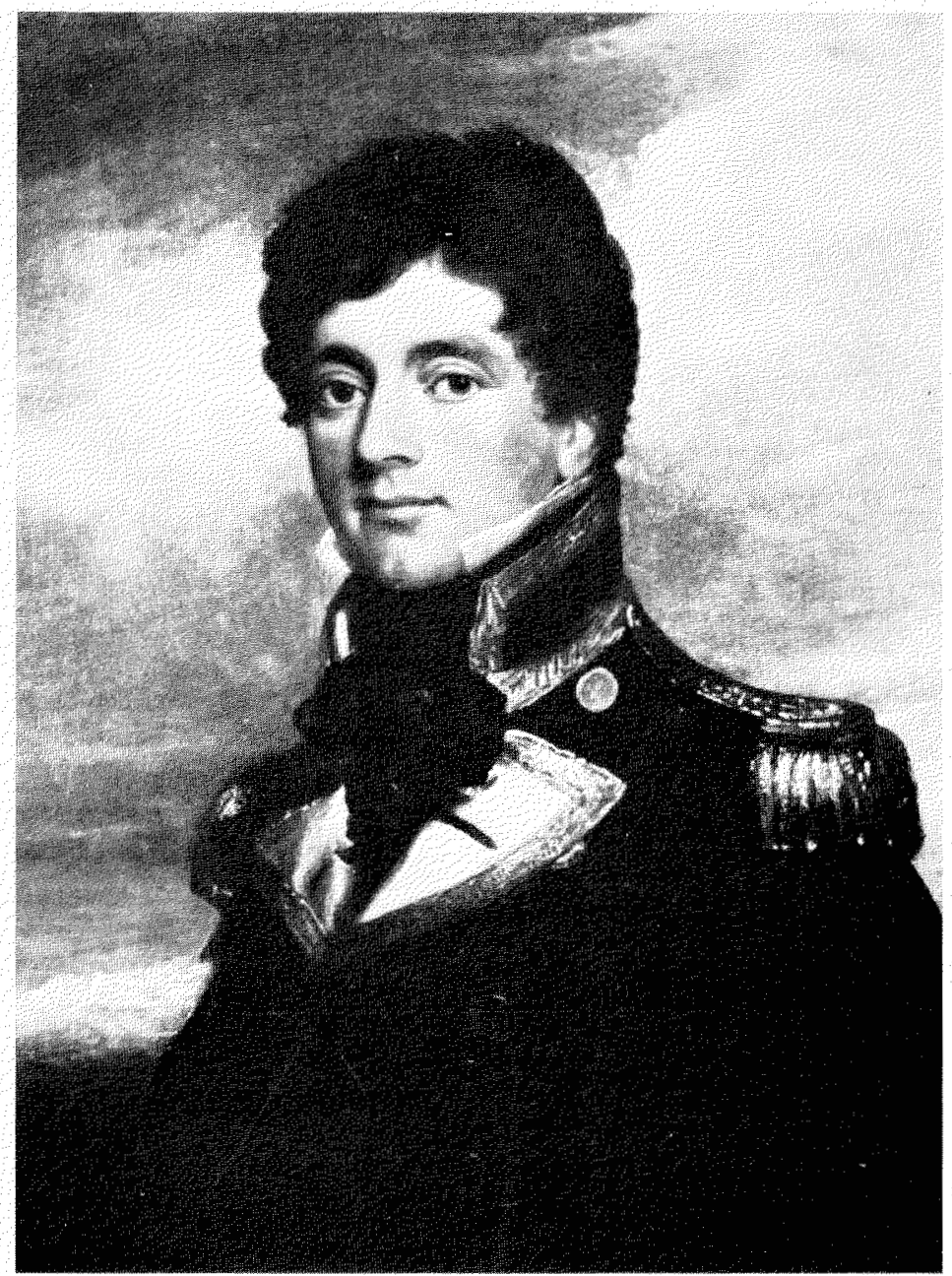

Portrait of Frederick William Beechey, by George Beechey; used with permission of The Hakluyt Society

Frederick William Beechey, named after his godfather William IV, was born in London on 17 February 1796, the second son of the eminent portrait artist Sir William Beechey, R.A. He served both the Royal Navy and geographical science with distinction, authored books on arctic discovery, and at the time of his death, 29 November 1856, was Vice President of the Royal Society and President of the Royal Geographical Society.

Beechey went to sea in $\mathbf{1 8 0 6}$ at the early age of ten, attaining midshipman's rank the following year. After nearly twelve years of active service, he began his career as arctic voyager and geographer. In 1818 he joined the Trent, a hired brig commanded by John Franklin, which was ordered to accompany H.M.S. Dorothea, under Captain David Buchan's command, on an attempted voyage across the Polar Sea. The next year he was appointed to the Hecla, Captain William Edward Parry, and made the remarkable voyage to "Parry's West", sharing the Parliamentary reward of $£ 5,000$. Upon his return, Beechey was appointed to the sloop Adventure from which he was dispatched with his brother Henry W. Beechey to conduct an overland survey of the northern coast of Africa. During this service he was promoted to the rank of commander. At the end of the voyage he seems to have been unemployed, perhaps for reasons of health after his physical exertions in the Arctic and in the desert country of Barca and Syrt. His next appointment was to the sloop Blossom on 12 January 1825.

The Blossom's object was to meet with Franklin's second overland expedition. She reached Kotzebue, via the Pacific, on 22 July 1826, and arrived at Chamisso Island on the 25th. Beechey was only five days late for his intended rendezvous with Franklin. A general reconnaissance of the surrounding country revealed it to be impenetrable, uninhabitable, and infested with mosquitoes. Consequently, Beechey decided not to send a party overland to the northern coast of America. He left provisions for Franklin at Chamisso and then took the Blossom northward in the hope of meeting him, charting the coastline as he proceeded. The Blossom's course was within sight of the shore, the 
barge skirting along as close as possible with her crew periodically erecting cairns and leaving bottles with messages for Franklin. Beechey's party had traced the coast to within twenty miles of Icy Cape when heavy weather set in, forcing the Blossom from shore and into ice floes. She was later able to return to the coast and rejoin the barge, which was then sent along the coast to find Franklin, who was expected daily. The Blossom herself returned to Chamisso to take on wood and water, strong westerly winds preventing her further use along the northern coast. On 23 August the barge reached its farthest east, $156^{\circ} 21^{\prime}$ W longitude, at Point Barrow, named after Sir John Barrow, the architect of the venture. Pack ice, moving sea ice astern, and warlike Eskimos forced even the barge to turn back at that point, but not before Beechey's party had added 126 miles of new coastline to the chart.

Franklin, meanwhile, had been making his way westward, surveying the coast to Beechey Point, $149^{\circ} 37^{\prime} \mathrm{W}$ longitude. He decided to go no farther than what he called Return Reef. This place, Franklin's farthest west, was reached on 18 August, five days before the barge, under Thomas Elson, made Point Barrow only 146 miles to the west. It would have been an historic meeting at that end of the earth. There is no doubt, however, that Elson and Franklin acted wisely in not pressing on in the face of early winter conditions. Neither knew, of course, of the other's position; in any case, had Franklin continued, he might not have been able to overtake the barge. Franklin was now forced to retrace his steps to Great Bear Lake, his object having again eluded him. It remained for two Hudson's Bay Company servants, Peter Warren Dease and Thomas Simpson, to complete the exploration of the western Arctic between Cape Barrow and Return Reef some ten years later, thus completing the outline of the shores of the Polar Sea.

While Franklin retraced his steps, the barge made a difficult retreat to the west and south. The ice was so close to the shore that the barge had to be tracked by rope, the crew scurrying along precipitous banks. The Eskimos were also difficult. The barge was reunited with the Blossom in Kotzebue Sound on 9 September, and even at that late date, Franklin might still be expected to arrive at the intended rendezvous. Beechey now had to decide how long he should wait. His vessel was not reinforced against the pressures of pack ice, and he had insufficient supplies to winter in the North, although his orders suggested that he should stay at the rendezvous until the end of October.
Nevertheless, with a sudden deterioration of the weather, Beechey and his officers agreed they must leave the sound and proceed southward for provisions, which they did on 14 October. As late as the 16th, Beechey was hoping for a change of wind that would allow him to return to Cape Krusenstern "in order to give Captain Franklin the last chance."

Beechey's second summer on the coast was equally disappointing, with even worse weather conditions than in the previous season. The barge was driven on shore during tempestuous weather in early September on the Choris Peninsula, Kotzebue Sound. She was wrecked and three of her crew drowned. It was also disappointing to Beechey that Franklin did not appear. Nor was there any news of him.

Beechey never returned to the Arctic, but the rest of his life was full of naval service and scientific inquiry. He surveyed South American waters and the coasts of Ireland, advancing to the rank of Rear-Admiral in 1854. The following year, Beechey was elected President of the Royal Geographical Society, and in his last annual address in that capacity he summed up the scientific aims of his life. He told his audience that after forty years, "the major problem," the Northwest Passage, had been solved "and Science at least had reaped her harvest." Arctic discovery had shown what men could endure with little loss of life, Sir John Franklin and his men notwithstanding. "They have, in short," he correctly concluded, "expunged the blot of obscurity which would otherwise have hung over and disfigured the history of this enlightened age."

\section{FURTHER READINGS}

BEECHEY, F.W. 1831. Narrative of a Voyage to the Pacific and Bering's Strait in His Majesty's Ship Blossom, 1825-28. London: H. Colburn and R. Bentley.

1843. Voyage of Discovery towards the North Pole, 1818. London: R. Bentley.

GOUGH, BARRY M. (ed.). 1973. To the Pacific and Arctic with Beechey: The Journal of Lieutenant George Peard of H.M.S. Blossom 1825-28. Cambridge: The Hakluyt Society.

\author{
Barry M. Gough \\ Department of History \\ Wilfrid Laurier University \\ Waterloo, Ontario, Canada \\ N2L 3C5
}

